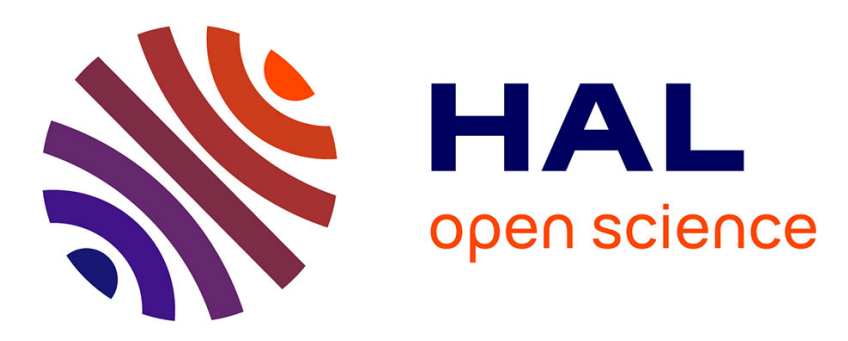

\title{
First direct age determination from the Jurassic radiolarian-bearing siliceous series (Jédidi Formation) of northwestern Tunisia
}

Fabrice Cordey, Mabrouk Boughdiri, Houaïda Sallouhi

\section{- To cite this version:}

Fabrice Cordey, Mabrouk Boughdiri, Houaïda Sallouhi. First direct age determination from the Jurassic radiolarian-bearing siliceous series (Jédidi Formation) of northwestern Tunisia. Comptes Rendus Géoscience, 2005, 337 (8), pp.777-785. 10.1016/j.crte.2005.03.013 . hal-03275269

\author{
HAL Id: hal-03275269 \\ https://hal.science/hal-03275269
}

Submitted on 30 Jun 2021

HAL is a multi-disciplinary open access archive for the deposit and dissemination of scientific research documents, whether they are published or not. The documents may come from teaching and research institutions in France or abroad, or from public or private research centers.
L'archive ouverte pluridisciplinaire $\mathbf{H A L}$, est destinée au dépôt et à la diffusion de documents scientifiques de niveau recherche, publiés ou non, émanant des établissements d'enseignement et de recherche français ou étrangers, des laboratoires publics ou privés. 
Rubrique : géologie / geology

Sous-rubrique : stratigraphie / stratigraphy

Première datation directe des séries siliceuses à radiolaires (formation Jédidi),

Jurassique du nord-ouest tunisien.

First direct age determination from the Jurassic radiolarian-bearing siliceous series (Jédidi Formation) of NW Tunisia.

Fabrice Cordey (*), Mabrouk Boughdiri (**), Houaïda Sallouhi (**)

(*) Université Claude Bernard Lyon 1, UFR des Sciences de la Terre, CNRS-UMR 5125

« Paléoenvironnements et paléobiosphère », 2 rue Dubois, 69622 Villeurbanne Cedex, France.

(**) Faculté des Sciences de Bizerte, Département des Sciences de la Terre, 7021 Jarzouna, Tunisie.

Correspondant: Fabrice Cordey, tél: 0472448374 fabrice.cordey@univ-lyon1.fr 


\title{
Résumé
}

Notre étude présente les résultats biostratigraphiques préliminaires obtenus sur les séries siliceuses jurassiques du nord-ouest tunisien. Pour la première fois, des radiolaires sont extraits de la Formation Jédidi et en permettent une datation directe. Ce sont aussi les premiers radiolaires documentés de Tunisie. Les deux niveaux datés ont un âge compris dans les intervalles 1. Bathonien supérieur-Callovien inférieur et 2. Bathonien supérieur-Oxfordien inférieur. Ces datations sont compatibles avec les dernières synthèses stratigraphiques proposées pour le Jurassique tunisien. Elles suggèrent en outre de corréler la formation Jédidi avec les séries siliceuses du Jurassique moyen-supérieur de la zone externe des Maghrébides, plutôt qu'avec les vraies unités océaniques associées aux flyschs maghrébins ou aux zones internes de Téthys occidentale.

\begin{abstract}
Our study presents preliminary biostratigraphic results from the Jurassic siliceous series of northwest Tunisia. For the first time, radiolarians are extracted from the Jédidi formation and provide a direct age determination. They are the first radiolarian fauna documented from Tunisia. Two age assignments have an age comprised within the following intervals: 1. late Bathonian-early Callovian, 2. late Bathonian-early Oxfordian. These ages are compatible with recent stratigraphic synthesis proposed for Jurassic series of Tunisia. The data suggest the correlation of the Jédidi formation with siliceous series of middle-late Jurassic age from the external zone of the Maghrebides belt rather than with true oceanic units from the Maghrebian flyschs or the internal zones of western Tethys.
\end{abstract}

Mots clefs : radiolarites, radiolaires, Jurassique, Tunisie, biostratigraphie, paléogéographie. Key words : radiolarites, radiolaria, Jurassic, Tunisia, biostratigraphy, paleogeography. 


\section{VERSION FRANCAISE ABREGEE}

\section{Introduction}

Depuis leur découverte dans les années 60, les séries siliceuses à radiolaires du nord-ouest tunisien ne bénéficiaient pas jusqu'à présent de contrôle stratigraphique direct, celui-ci étant basé sur des corrélations lithologiques ou par encadrement. Nous présentons ici les premiers résultats biostratigraphiques obtenus sur ces séries en documentant les faunes de radiolaires extraites de la coupe-type de la formation Jédidi (figures 1, 2). Grâce à elles, nous proposons de préciser les corrélations stratigraphiques ainsi que le contexte paléogéographique associé à ces séries.

\section{Cadre stratigraphique et études antérieures}

Pour une revue complète de la stratigraphie des séries jurassiques de l'Atlas tunisien, on se réfèrera aux publications de Soussi [22] [23] [24] [25] [26]. La Dorsale tunisienne comprend des séries de plate-forme (Zaghouan) et de pente (Hammam-Lif), tandis que le sillon tunisien est caractérisé par des séries de bassins où se développent au Jurassique moyen-supérieur les séries siliceuses à radiolaires de la formation Jédidi ("H”, figure 2). Ces séries ont d'abord été considérées comme d'âge crétacé [20] [5] [6]. Les premiers affleurements qualifiés de jurassiques des jebels Jédidi, Chaâbane et Tamrhoura ont été découverts par Pini et Salaj [17], puis un équivalent latéral de ces dépôts a été décrit par Glaçon et Rouvier [11] dans la région de Thuburnic. Plus tard, Rouvier [19] affine l'âge de la série en l'attribuant par encadrement au Kimméridgien-Tithonien. La première appellation de « radiolarites » est due à Alouani et al. [1] qui attribuent cette formation à l'Oxfordien supérieur-Kimméridgien inférieur par corrélations lithologiques. Peybernès et al. [16] décrivent ensuite (région de Sidi Thabet) des alternances de pélites et de marno-calcaires pouvant passer latéralement (région de Mejez el $\mathrm{Bab}$ ) à un complexe rouge/vert de pélites à radiolaires et de radiolarites (jaspes) dit «faciès 
Jédidi » et proposent un âge Kimméridgien supérieur-Tithonien supérieur. Sur la base de leur nouvelle attribution des calcaires noduleux gris rougeâtre à la formation Kef el Orma (plutôt qu'à la formation Zaress comme proposé dans les corrélations de [16]) et grâce à de nouvelles faunes d'ammonites provenant des séries adjacentes récoltées au jebel Ammar et à l'affleurement de Thuburnic, Soussi et al. [23] révisent les attributions antérieures et invoquent un âge Bajocien supérieur-Oxfordien supérieur pour ces séries siliceuses. Soussi [22] y définit une nouvelle formation dans la coupe-type du jebel Jédidi-Chaâbane qu'il étend aux affleurements des jebels Tamrhoura, oued Maâden (ou Thuburnic) et Ammar. Dans tous ces travaux, les évaluations d'âge de ces séries siliceuses sont basées sur des données stratigraphiques indirectes.

\section{Localisation et description de la coupe-type de la formation Jédidi}

La coupe-type de la formation Jédidi est située à 10 km à 1'ouest de la ville de Mejez el Bab, dans la partie orientale du jebel Sidi Jédidi (figure 1). Au-dessus des calcaires noduleux grisrougeâtre (Formation Kef el Orma, reconnue par [23] dans le secteur d'étude), la coupe peut être subdivisée en trois unités (figure 3):

Unité U1 : à dominance de pélites rouge-brique, elle intègre deux bancs décimétriques de calcaires siliceux stratifiés brun-rouge. Le faciès siliceux peut varier au sein d'un même banc. Unité U2 : elle se distingue de l'unité sous-jacente par la dominance des bancs carbonatés et une nette diminution en épaisseur des niveaux pélitiques. Ces bancs durs sont plus épais et de teinte plus sombre que ceux de l'unité U1.

Unité U3 : ressemble à U1 ; les bancs calcaires sont peu épais, rouge-brique ou vert clair et s'appauvrissent en silice vers le sommet de la série, passant progressivement aux alternances marno-carbonatées de la formation Beni Kleb [15]. 
Bien que la formation Jédidi comprenne plusieurs niveaux de jaspes biosiliceux primaires à radiolaires, elle ne correspond pas à une formation radiolaritique s.s., contrairement à ce qui a été décrit auparavant [1] [22]. Les radiolarites sont en effet caractérisées par des alternances de jaspes et de pélites dépourvus de carbonates et issus à 80-90\% de 1'accumulation de tests de radiolaires. Or la formation Jédidi comprend plusieurs intercalations carbonatées et marneuses (figure 3) où les radiolaires sont fréquemment calcitisés. Par ailleurs, certains niveaux de jaspes sont en fait des bancs de calcaires silicifiés. La formation Jédidi devrait donc, à notre avis, être décrite comme une série « siliceuse ». Il n’y a pas, à notre connaissance, de radiolarites vraies en Tunisie. En terme d'environnement de dépôt, la présence de radiolaires dans une matrice carbonatée suggère que les dépocentres associés étaient liés à une forte productivité planctonique et que la sédimentation, bien que probablement soumise à un approfondissement, se soit effectuée au-dessus de la CCD en milieu bathyal.

\section{Assemblages de radiolaires et âges}

Des tentatives précédentes de datation de la formation Jédidi n'ont pas conduit à l'extraction de radiolaires identifiables (R. Enay, com. pers., 2004). Nous avons intégré dans notre approche une sélection d'échantillons sur le terrain [7] puis un traitement chimique HF de faible concentration (5\%). Jusqu'à présent, deux niveaux ont livré des assemblages diagnostiques. MB4 (figures 3, 4) contient: Cinguloturris carpatica Dumitrica, Palinandromeda podbielensis (Ozvoldova), Parahsuum sp., Parvicingula sp. aff. blackhornsensis Pessagno et Whalen, Protunuma sp., ?Sethocapsa sp., Stichocapsa robusta Matsuoka, Transhsuum brevicostatum (Ozvoldova), Transhsuum maxwelli (Pessagno), Tricolocapsa plicarum Yao, ?Tricolocapsa sp.. Ces morphotypes sont présents dans la zonation de Baumgartner et al. basée sur la méthode des Associations Unitaires [2]. Ils sont corrélés à l'UAZ 7 d'âge Bathonien supérieur ou Callovien inférieur. Le second échantillon 
productif, MB18, comprend: Protunuma sp., Sethocapsa sp., Transhsuum maxwelli

(Pessagno), Williriedellum sp. A sensu Matsuoka, et Wrangellium sp. ; cet assemblage peut être attribué aux UAZ 4-8. La présence d'UAZ 7 dans l'échantillon MB4 permet de réduire l'attribution de MB18 aux UAZ 7-8, correspondant à un âge compris dans l'intervalle Bathonien supérieur-Oxfordien inférieur. Ce sont les premières datations directes obtenues sur des séries siliceuses tunisiennes. Ce sont aussi les premiers radiolaires documentés de Tunisie. Les âges obtenus sont, pour l'instant, compatibles avec les évaluations antérieures effectuées par encadrement à partir des formations sous-jacente Kef el Orma et sus-jacente Beni Kleb d'âge Bajocien supérieur à Oxfordien supérieur respectivement [23] [22] [12]. Il sera cependant nécessaire de dater plus précisement la base et le sommet de la formation Jédidi.

\section{Discussion}

Alouani et al. [1] ont interprété la formation Jédidi et les séries de bassins associées comme les premiers dépôts pélagiques ayant suivi un effondrement généralisé du sillon tunisien au Jurassique moyen-supérieur. La datation directe, bien que partielle, de la formation Jédidi apporte un argument pour associer les dépôts pélagiques du sillon tunisien aux formations biosiliceuses reconnues comme « radiolarites » dans la zone externe des Maghrébides (Kabylies situées au NW de Constantine, Algérie) pour lesquelles un âge comparable (Dogger-Malm) a été attribué [9]. Bien que la paléoécologie des radiolaires mésozoïques soit toujours un sujet débattu [18], la période étudiée semble correspondre à une combinaison de conditions de forte productivité planctonique et d'un approfondissement progressif de segments externes de marges de la Téthys occidentale. L'absence de "vraies" radiolarites en Tunisie est à mettre en parallèle avec l'absence de vraies ophiolites montrant une absence d'océanisation, celle-ci concernant plutôt l'unité des flyschs maghrébins (voir schéma synthétique de [13]) ou les unités internes des régions de Téthys occidentale [8]. 


\section{ENGLISH VERSION}

\section{Introduction}

Since their discovery in the 60ies, radiolarian-bearing siliceous units of NW Tunisia underwent several stratigraphic correlations. These series had no direct age attribution so far, these being based on lithological correlations and/or from biostratigraphic data obtained from underlying and overlying units (see below). We present here the first direct age controls on these siliceous units by documenting radiolarian fauna extracted from the type-section of the Jédidi formation (Mejez el Bab region) (figures 1, 2). We propose to discuss previous correlations, as well as place these biosiliceous successions in their regional, west Tethyan paleogeographic setting.

\section{Stratigraphic framework and previous studies}

For a complete overview of Jurassic stratigraphy from the Tunisian Atlas, see [22] [23] [24] [25] [26]. In the Jurassic series, the facies heterogeneity observed in the Early Jurassic is accentuated during the Middle and Late Jurassic (figure 2). The Tunisian "Dorsale" documents platform (Zaghouan) and slope-type deposits (Hammam-Lif), whereas NorthAtlasic Tunisia comprises basinal successions (Tunisian trough), where the Jédidi formation is represented ("H", figure 2). Originally, the siliceous successions from Tunisia were broadly attributed to the lower Cretaceous [20] [5] [6]. From jebels Jédidi, Chaâbane and Tamrhoura, exposures of siliceous series were discovered by Pini and Salaj [17] who identified a thick succession $(70 \mathrm{~m})$ of reddish limestones yielding chloritized radiolarians attributed to the Callovian-Oxfordian interval by comparison with known successions of northern Tunisia. A lateral equivalent to these biosiliceous deposits was discovered by Glaçon and Rouvier [11] in Thuburnic area (region of Ghardimaou, NW Tunisia). Later on, Rouvier [19] assigned the «green radiolarian jaspers» to the Kimmeridgian-Tithonian interval. The first attribution to 
« true » radiolarian chert for these siliceous successions is from Alouani et al. [1] who inferred a late Oxfordian-lower Kimmeridgian age range, by comparison with the stratigraphy of Ammonitico-rosso unit (Zaress formation) from the Tunisian "Dorsale", as well as the occurrence of Kimmeridgian ammonites within overlying limestones. Then Peybernès et al. [16] described at Jebel Ammar (region of Sidi Thabet, northern Tunisia) alternations of red to green pelites and limestones-marls which could laterally grade into red/green radiolarianbearing pelites and radiolarites called «Jédidi facies» previously described [1]. Peybernès et al. proposed a late Kimmeridgian-late Tithonian age ([16] fig. 2, p. 158). Taking into account their new attribution of the underlying nodular limestones to the Kef el Orma Fm (rather than to the Zaress Fm as proposed in correlations by [16]) and on the basis of new ammonite fauna from adjacent series gathered at J. Ammar and Thuburnic, Soussi et al. [23] revised previous correlations and assessed a late Bajocian-late Oxfordian age for the siliceous series of NW Tunisia. Soussi [22] defined a new formation at the type-locality of Jebel Jédidi-Chaâbane, including exposures from jebels Tamrhoura, Oued Maâden (or Thuburnic) and Ammar. All these biochronological attributions were based on indirect evidence.

\section{Location and lithology of type-section}

The studied section is located $10 \mathrm{~km}$ to the west of the town of Mejez el Bab, near highway $\mathrm{n}^{\circ} 6$ linking Tunis to Ghardimaou (figure 1). Between Mejez el Bab and Oued Zarga, a gravel road heads south to Sidi Ahmed Jédidi, then to the SE flank of jebels Sidi Jédidi and Chaâbane, where the section is exposed (figure 1, B). Within the range, Jurassic units are bounded to the south by the Téboursouk fault (figure 1, A), cropping out along a NE-SW belt parallel to large exposures of Triassic salt formations bordering the fault. Lower Jurassic limestones, presently worked in a gravel quarry, bound the Jurassic southernmost exposures. Jurassic units extend to the north as the base of a wide syncline where are identified subvertical to slightly reversed Middle and Late Jurassic strata. These strata grade into 
Cretaceous (vast plain crossed by Ghardimaou highway) and Eocene successions (ToukabeurChaouache area).

The Jédidi formation type-section can be subdivided into three lithological units (figure 3). The base of the formation overlies a layer of pink-grey nodular limestone containing belemnites (Formation Kef el Orma as recognized by [23] in the study area and maintained in this paper:

Unit U1 : dominantly composed of thick red pelites (locally not exposed), this unit comprises two beds of thinly laminated siliceous limestone, dark brown to brick red in colour with tints of yellow and green. The siliceous content varies along beds. Locally, these beds display potentially radiolarian-rich layers.

Unit U2 : it differs from the underlying unit by a lesser amount of pelites and siliceous facies. Calcareous beds are dominant and are harder, thicker and darker than those of U1.

Unit U3 : resembles U1. Limestone beds are relatively thin, red or green in colour, along with decreasing siliceous content towards the top of the formation, grading into marl-limestone alternations of the Beni Kleb formation [15].

Although the Jédidi formation comprises several layers of primary radiolarian-bearing biogenic chert, we consider it as improperly described in the literature as "radiolarites" [1] or “pseudoradiolarites" [22]. True radiolarites (also classically named "radiolarian chert", "ribbon chert", or "bedded chert") are typically composed of alternations of chert-shale couplets devoid of limestone layers, whereas the Jédidi formation comprises several intercalations of limestone beds and marls in which the siliceous component is present (as shown by occurrence of radiolarians) but obviously not dominant. Although some beds are composed of biosiliceous jasper, others apparent "radiolarite" beds are actually silicified limestone layers (figure 3). Occurrence of calcium carbonate is observed within the entire 
succession (units 1 to 3). The presence of radiolarians is significant but cannot be considered the dominant lithological component, as is the case in a true primary biosiliceous succession. There is, to our knowledge, no true radiolarite formation in Tunisia. In summary, the so-called "radiolarites" of the Jédidi formation should instead be described as "siliceous series". In terms of depositional environments, the occurrence of carbonates within these siliceous successions suggests that related depocenters, although basinal and potentially deep, were located above the CCD and probably linked with a high siliceous productivity. Such successions are usually found in bathyal environments.

\section{Radiolarian assemblages and age correlations}

Previous attempts for extracting radiolarians from the Jédidi formation were undertaken without success (R. Enay, pers. com., 2004). Our approach included field selection of appropriate samples [7], then processed in the HF laboratory of the University Claude Bernard Lyon 1. As is usually applied to biosiliceous samples, low concentration HF etching procedures were undertaken. So far, two layers released diagnostic radiolarians. Sample MB4

(figure 3) from the base of U2 contains the following association (figures 3, 4): Cinguloturris carpatica Dumitrica, Palinandromeda podbielensis (Ozvoldova), Parahsuum sp., Parvicingula sp. aff. blackhornsensis Pessagno and Whalen, Protunuma sp., ?Sethocapsa sp., Stichocapsa robusta Matsuoka, Transhsuum brevicostatum (Ozvoldova), Transhsuum maxwelli (Pessagno), Tricolocapsa plicarum Yao, ?Tricolocapsa sp.. These identified morphotypes are present within the Unitary Association Zonation of Baumgartner et al. [2], showing a common occurrence within the UAZ 7 of late Bathonian or early Callovian age [2]. Although we do not use the following taxon in our correlation due to slight morphological differences, Parvicingula blackhornsensis Pessagno and Whalen, reported and described from the Snowshoe formation, Oregon [14] is of late Bathonian-Callovian age pro parte, an age consistent with our age establishment. 
The second productive sample MB18, collected from the upper part of U2, contains (figures 3, 4): Protunuma sp., Sethocapsa sp., Transhsuum maxwelli (Pessagno), Williriedellum sp. A sensu Matsuoka and Wrangellium sp.. Zonation [2] shows that this association is correlative with UAZ 4-8. The occurrence of UAZ 7 in MB4 establishes that MB18 can be attributed to UA7-8, corresponding to an age placed within the interval late Bathonian-early Oxfordian.

These age data provide, for the first time, a direct age control on the Jurassic radiolarianbearing siliceous strata from Tunisia. As precised in the stratigraphic framework above, the age of the Jédidi formation was previously assessed indirectly from the underlying Kef el Orma and the overlying Beni Kleb formations, providing a late Bajocian to late Oxfordian age range [23] [22] [12]. Our data are compatible with this assessment. More diagnostic layers need to be found in the future, for instance radiolarian-bearing beds near the base and the top of the Jédidi formation.

\section{Discussion}

Within the Tunisian "Dorsale", the transition between middle and late Jurassic successions is characterized by the onset of «Ammonitico Rosso» facies, usually of middle Callovian (Anceps zone) up to late Oxfordian (Bimammatum and/or Planula zones) age range. At Bou Kornine du Pont de Fahs, Raouas-Beni Kleb, Aziz, Oust and Ammar jebels, these series are instead represented by a thick succession of greenish or dark-red limestones ("faciès ocellés" [3] or Fahs formation sensu Soussi [22]). The siliceous series of the Jédidi formation probably represent for their upper part a lateral equivalent, within the Tunisian trough, of these carbonate successions. The lower part of the formation can also be correlated to part of, or the whole of Bent Saïdane Fm (figure 2). 
In their discussion, Alouani et al. [1] have interpreted the siliceous Jédidi formation and associated Jurassic basinal units as the first pelagic deposition following a general collapse of the Tunisian trough area. The direct, although partial, age assignment of the siliceous deposits of the Jédidi formation provides an argument for integrating the pelagic deposits of the Tunisian trough into the biosiliceous series identified in the external Maghrebide Range (e.g. Kabylias located to the NW of Constantine, Algeria) to which the same middle-?late Jurassic age was assigned [9]. Although the conditions of radiolarian paleoecology is still a matter of debate (see [18] and references therein), this period is a combination of high productivity siliceous depocenters as well as a general deepening of segments of west circumtethyan passive margins. The absence of true Jurassic radiolarites is to be paralleled with the absence, in Tunisia, of true ophiolites, suggesting a lack of true oceanization found instead within the Maghrebian flyschs unit [13] and in the internal zones of western Tethys [8].

\section{Conclusion}

Appropriate radiolarian detection and extraction techniques show their potentiel for directly dating Jurassic siliceous series of Tunisia. Although more work is probably needed, the typesection of the Jédidi formation released so far two assemblages of late Bathonian-early Callovian and late Bathonian-early Oxfordian ages respectively. These results show that the Jédidi formation is partly coeval to radiolarite successions from the Mediterranean region. However, they suggest that the Jurassic siliceous series of the Tunisian trough are to be correlated with units from the external zone of the Maghrebides belt rather than true oceanic units from western Tethys.

\section{Acknowledgments}


FC wishes to thank the staff of the Department of Earth Sciences from Bizerte University as well as Dr. Ben Youssef (CINRST) for their help and support. Funds were in part provided by the laboratory "Eau-Technologie membranaire" (INRST, Tunisia) supervised by P. Mahmoud Dhahbi.

\section{References}

[1] R. Alouani, S. Tlig, F. Zargouni, Découverte de radiolarites du Jurassique supérieur dans le "sillon tunisien": faciès et structures d'une marge SE de la Téthys, C. R. Acad. Sci. Paris, 310, ser. 2 (1990) 609-612.

[2] P.O. Baumgartner, A. Bartolini, E.S. Carter, M. Conti, G. Cortese, T. Danelian, P. De Wever, P. Dumitrica, R. Dumitrica-Jud, S. Gorican, J. Guex, D.M. Hull, N. Kito, M. Marcucci, A. Matsuoka, B. Murchey, L. O’Dogherty, J. Savary, V. Vishnevskaya, D. Widz, A. Yao, A., Middle Jurassic to Early Cretaceous radiolarian biochronology of Tethys based on Unitary Associations, in Middle Jurassic to Lower Cretaceous Radiolaria of Tethys : occurrences, systematics, biochronology, P.O. Baumgartner (project leader); Mémoires Géol., Lausanne, $n^{\circ} 23$ (1995) 1013-1048.

[3] J. Bonnefous, Contribution à l'étude stratigraphique et micropaléontologique du Jurassique de Tunisie (Tunisie septentrionale et centrale, Sahel, zone des Chotts), thèse Doct. Etat, Univ. Paris VI, 1972, 1-397.

[4] M. Boughdiri, F. Olóriz, B. López Márques, M. Layeb, E. De Matos, H. Sallouhi, Upper Kimmeridgian and Tithonian Ammonites from the Tunisian «Dorsale » (NE Tunisia) : updated biostratigraphic results from J. Oust, Riv. Ital. Biostr. Paleont., in press. G. Castany, Etude géologique de l'Atlas tunisien oriental, Ann. Mines et Géol. Tunisie, 8 (1951) 1-632. 
[6] G. Castany, Les extrusions jurassiques en Tunisie, Ann. Mines et Géol. Tunisie, 14, $1955,1-71$.

[7] F. Cordey, P. Krauss, A field technique for identifying and dating radiolaria applied to British Columbia and Yukon, Geol. Surv. of Canada Paper 90-1E (1990) 127-129.

[8] P. De Wever, J. Azéma, E. Fourcade, Radiolaires et radiolarites: production primaire, diagénèse et paléogéographie, Bull. Centre Rech. Explor.-Prod. Elf-Aquitaine, 18 (1994) 316379.

[9] M. Durand-Delga, Etude géologique de l'Ouest de la chaîne numidique, Thèse d'Etat ès. Sci. Naturelles, Fac. Sci. Univ. Paris, sér. A, 2755 (1955) 1-533.

[10] P. Fauré, B. Peybernès, Biozonation par ammonites et essai de corrélation des séries réduites liasiques de la «Dorsale tunisienne », Bull. Soc. Hist. Nat. Toulouse, 122 (1986) 4149.

[11] G. Glaçon, H. Rouvier, Découverte de Jurassique dans les monts de la moyenne Medjerda (Tunisie septentrionale), C. R. Acad. Sci. Paris, sér. D, 270 (25) (1970) 3007-3009. [12] K. Maâlaoui, Repères biochronologiques dans la série du Dogger-Berriasien du J. Ammar (Ariana, Tunisie septentrionale) : Biomicrofaciès et cadre géodynamique régional, unpub. MSc thesis, Fac. Sci. Bizerte, 2004, 100 p..

[13] A. Michard, A. Chalouan, H. Feinberg, B. Goffé, R. Montigny, How does the Alpine belt end between Spain and Morocco? Bull. Soc. géol. France, 1 (2002), 3-15.

[14] E. A. Pessagno Jr, P.A. Whalen, Lower and Middle Jurassic radiolaria (multicyrtid Nassellariina) from California, east-central Oregon and the Queen Charlotte Islands, B.C.; Micropaleontology, v. 28 (2) (1982) 111-169.

[15] B. Peybernès, The Jurassic of Tunisia: an attempt at reconstitution of the SouthNeotethyan margin during and after the rifting phase, Geology of Libya, Elsevier (1992) 1679-1766. 
[16] B. Peybernès, F. Kamoun, M. Durand-Delga, J. Thierry, P. Fauré, J.-L. Dommergues, J.-M. Vila, P. Cugny, M. Ben Youssef, Le Jurassique et le Crétacé basal de la Tunisie atlasique nord-occidentale : essai de corrélations avec les formations de la Dorsale tunisienne et de la « ride » Amar-Djédeida, C. R. Acad. Sci. Paris, sér. II a, 323 (1996) 153-162.

[17] S. Pini, J. Salaj, Découverte de Jurassique à l'Ouest de Medjez el-Bab (Tunisie septentrionale), Notes Serv. Géol. Tunisie, 31 (1969) 25-36.

[18] G. Racki, F. Cordey, Radiolarian paleoecology and radiolarites: is the present the key to the past?, Earth Sc. Rev., 52 (2000) 83-120.

[19] H. Rouvier, Géologie de l'extrême Nord tunisien : tectonique et paléogéographies superposées à l'extrémité orientale de la chaîne nord-maghrébine, Ann. Mines et Géol. Tunisie, 29, 1985, 1-427.

[20] M. Solignac, Etude géologique de la Tunisie septentrionale, Thèse Doct. Fac. Sci., Lyon. Barlier, 1927, 1-756.

[21] H. Sallouhi, Biostratigraphie intégrée (Ammonites, Calpionelles) dans le Kimméridgien supérieur-Tithonien du Jebel Oust (NE Tunisie) : approche biogéographique et facteurs de contrôle du renouvellement de la faune, unpub. M. Sc., Fac. Sc. Bizerte, 2003, 1119.

[22] M. Soussi, Nouvelle nomenclature lithostratigraphique « événementielle » pour le Jurassique de la Tunisie atlasique, Geobios, 36 (2002), 761-773.

[23] M. Soussi, M. Boughdiri, R. Enay, C. Mangold, Faciès à affinité ammonitico rosso d'âge Toarcien supérieur de la Tunisie atlasique nord-occidentale. Conséquences pour les corrélations et la paléogéographie, C. R. Acad. Sci. Paris, sér. 2, 327 (1998), 135-140.

[24] M. Soussi, R. Enay, M. Boughdiri, C. Mangold, D. Zaghbib-Turki, L'AmmoniticoRosso (Formation Zaress) de la Dorsale tunisienne, C. R. Acad. Sci. Paris, 329, 4, sér. 2 (1999), 279-286. 
[25] M. Soussi, R. Enay, C. Mangold, M.M. Turki, The Jurassic events and their sedimentary and stratigraphic records on the Southern Tethyan margin in Central Tunisia. In: Crasquin-Soleau, S., Barrier, E. (eds.), Peri-Tethys Memoir 5 : new data on Peri-Tethyan sedimentary basins; Mém. Muséum Hist. Nat., 182, 2000a, 57-92.

[26] M. Soussi, C. Mangold, R. Enay, M. Boughdiri, M. H. Ben Ismaïl, Le Jurassique inférieur et moyen de la Tunisie septentrionale. Corrélations avec l'axe Nord-Sud et paléogéographie, Geobios, 33 (4) (2000b), 437-446. 


\section{Légendes des figures}

\section{Legends of figures}

Figure 1. Localisation de la zone d'étude.

A: Nord Tunisie. 1 : chevauchement; 2 : faille majeure; 3 : fossé d'effondrement; 4 :

affleurements jurassiques; 5 : affleurements triasiques; 6 : zone d'étude.

B: Région de la coupe-type de Jédidi. 1 : route principale; 2 : piste; 3 : courbe de niveau; 4 :

ravin, oued; 5 : voie ferrée. "A-B": coupe étudiée (coordonnées de la base de la coupe: N 36³9’06,0” E 009³0'56,7”).

Figure 1. Location of study area.

A: northern Tunisia. 1: thrust fault; 2: main fault; 3: through; 4: Jurassic exposures; 5: Triassic exposures; 6: study area.

B: Area of Jédidi type-section. 1: highway; 2: gravel road; 3: elevation; 4: creek; 5: railway tracks. “A-B”: studied section (coordinates for section base: N 36³9’06,0” E 009³0’56,7”).

Figure 2. Charte stratigraphique et répartition des faciès en Tunisie septentrionale au cours de l'intervalle Dogger-Berriasien (d'après [22], légèrement modifiée; quelques nouveaux résultats par [21] [4] [12]. Faciès : A : calcaires fins à ammonites, «filaments », Zoophycos et silex ; B : marno-calcaires à ammonites, «filaments » et Zoophycos; C : calcaires noirs à « filaments »; D : brèches de Bou Kornine ; E : marnes calcaires siliceuses ; F : marnes et calcaires noduleux rouges, faciès « ammonitico rosso »; G : calcaires argileux ou durs siliceux (« faciès ocellé »); H : séries siliceuses de la Formation Jédidi ; I : calcaires pélagiques à Saccocoma; $\mathrm{J}$ : calcaires lités ou pseudobréchiques à calpionelles ; K : calcaires subrécifaux de la formation Ressas. 
Figure 2. Stratigraphic chart and facies distribution in northern Tunisia during the interval Middle Jurassic-Early Cretaceous (after [22] with minor modifications; some new results by [21] [4] [12]. Facies : A : fine-grained limestones with ammonites, "filaments", Zoophycos and flint; B : marly limestones with ammonites, "filaments" and Zoophycos ; C : black limestones with "filaments"; D : Bou Kornine breccia; E : siliceous limy marls ; F : limestones and red nodular marls, « ammonitico rosso » facies; G : limestones, shaly or siliceous (« faciès ocellé »); $\mathrm{H}$ : siliceous series of the Jédidi formation; I : pelagic limestones with Saccocoma ; J : limestones, laminated or pseudobrecciated with calpionellids ; K : subreefoidal limestones of Ressas formation.

Figure 3. Coupe-type de la formation Jédidi, assemblages de radiolaires et âges attribués. 1 : calcaire pseudo-noduleux ; 2 : pélites à radiolaires ; $3:$ pélites à intercalations de minces bancs calcaires ; 4 : calcaire siliceux, jaspe à radiolaires ; $5:$ calcaire ; $6:$ marnes. Colonne de gauche : incertitude sur la position des limites d'étages.

Figure 3. Type-section of the Jédidi formation, radiolarian assemblages and age correlations. 1: nodular limestone; 2 : radiolarian-bearing pelites; 3 : pelites with thin limestone beds intercalations; 4 : radiolarian chert or siliceous limestone; 5 : limestone; 6 : marls. Arrows within left column: lack of constraint on stage boundaries.

Figure 4. Radiolaires jurassiques de la formation Jédidi, Tunisie (Microscope Electronique à Balayage). Mentions: taxon, échantillon, $\mathrm{n}^{\circ}$ de cliché, trait d'échelle.

Figure 4. Jurassic radiolarians from the Jédidi Formation, Tunisia (Scanning Electron Microscope). Mentions: taxon, sample, picture number, scale length. 
1. Palinandromeda podbielensis (Ozvoldova), MB4, $\mathrm{n}^{\circ}$ 15, $200 \mu \mathrm{m}$.

2. Stichocapsa robusta Matsuoka, MB4, $\mathrm{n}^{\circ} 1,110 \mu \mathrm{m}$.

3. Tricolocapsa plicarum Yao, MB4, $\mathrm{n}^{\circ}$ 9, $120 \mu \mathrm{m}$.

4. Protunuma sp., MB4, $\mathrm{n}^{\circ} 6,100 \mu \mathrm{m}$.

5. ?Tricolocapsa sp., MB18, $\mathrm{n}^{\circ} 17,90 \mu \mathrm{m}$.

6. ?Sethocapsa sp., MB18, $\mathrm{n}^{\circ} 7,110 \mu \mathrm{m}$.

7. ?Sethocapsa sp., MB4, $\mathrm{n}^{\circ} 05,100 \mu \mathrm{m}$.

8. Williriedellum sp. A sensu Matsuoka, MB18, ${ }^{\circ} 19,100 \mu \mathrm{m}$.

9. Parahsuum sp., MB4, $\mathrm{n}^{\circ} 16,100 \mu \mathrm{m}$.

10. Parvicingula sp. aff. blackhornsensis Pessagno and Whalen, MB4, $\mathrm{n}^{\circ} 19,100 \mu \mathrm{m}$.

11. Transhsuum brevicostatum (Ozvoldova), MB4, $\mathrm{n}^{\circ}$ 9, $110 \mu \mathrm{m}$.

12. Cinguloturris carpatica Dumitrica, MB4, $\mathrm{n}^{\circ} 21,90 \mu \mathrm{m}$.

13. Cinguloturris carpatica Dumitrica, MB4, $\mathrm{n}^{\circ} 23,80 \mu \mathrm{m}$.

14. Transhsuum maxwelli (Pessagno), MB4, $\mathrm{n}^{\circ} 13,90 \mu \mathrm{m}$.

15. Wrangellium sp., MB18, $\mathrm{n}^{\circ} 2,100 \mu \mathrm{m}$. 

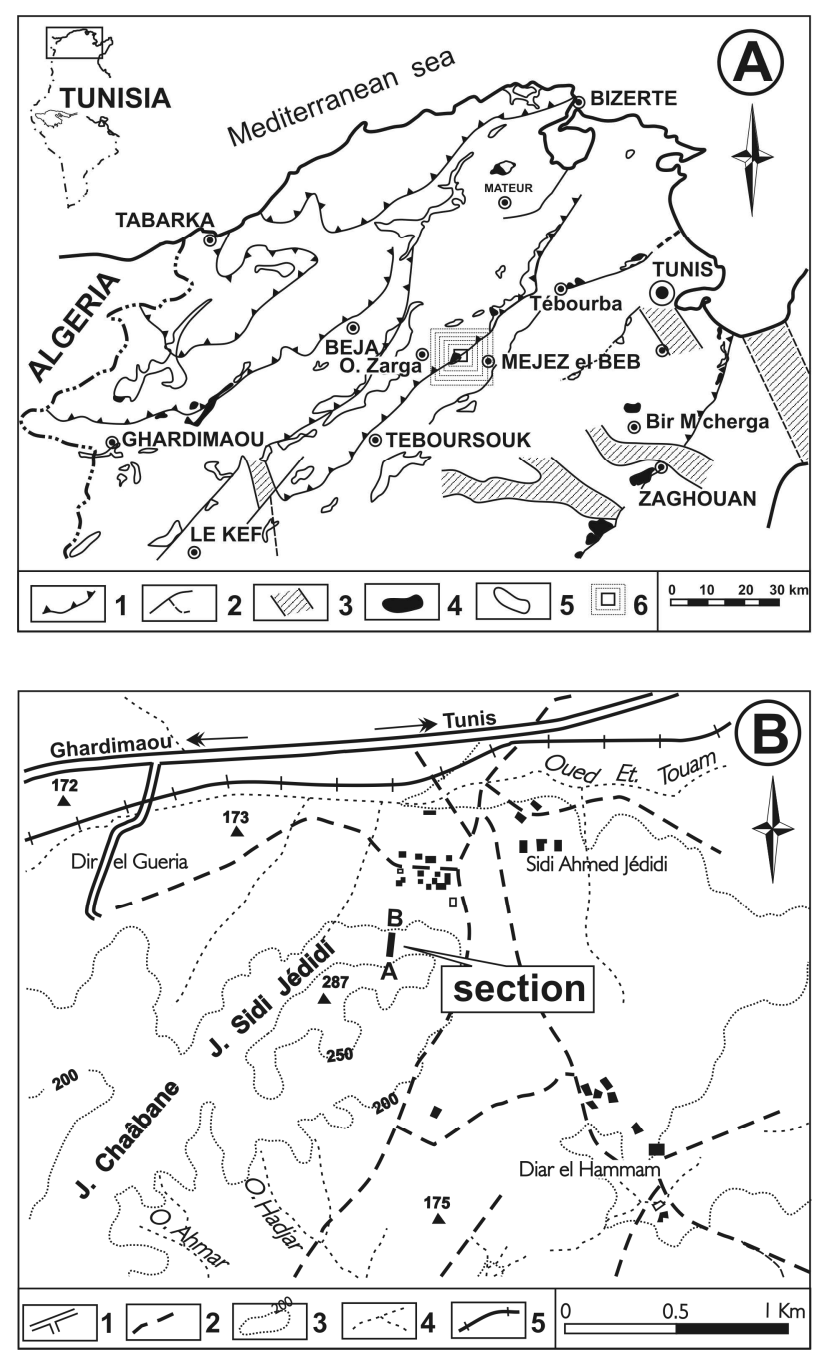

Figure 1 


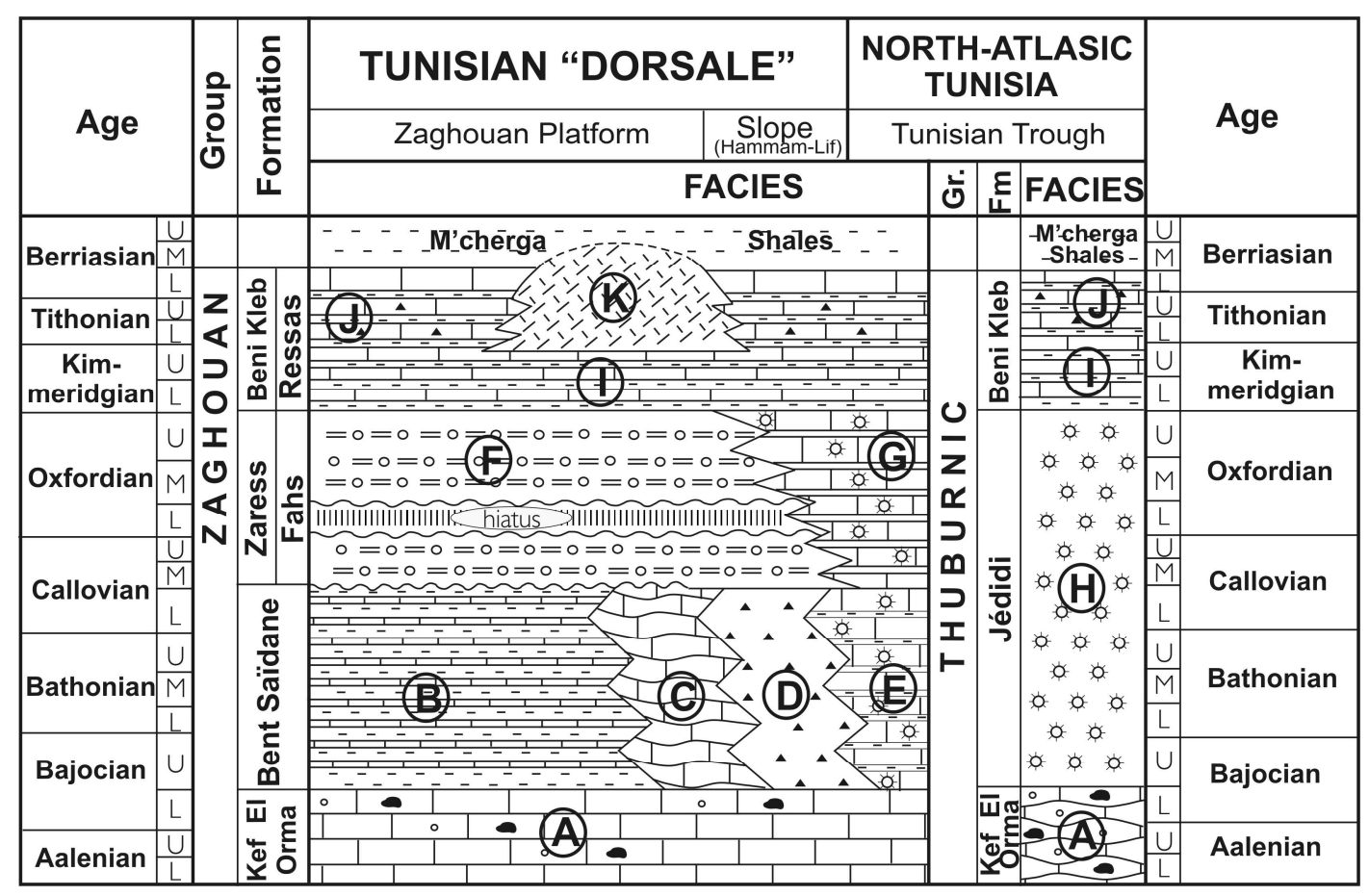

Figure 2 


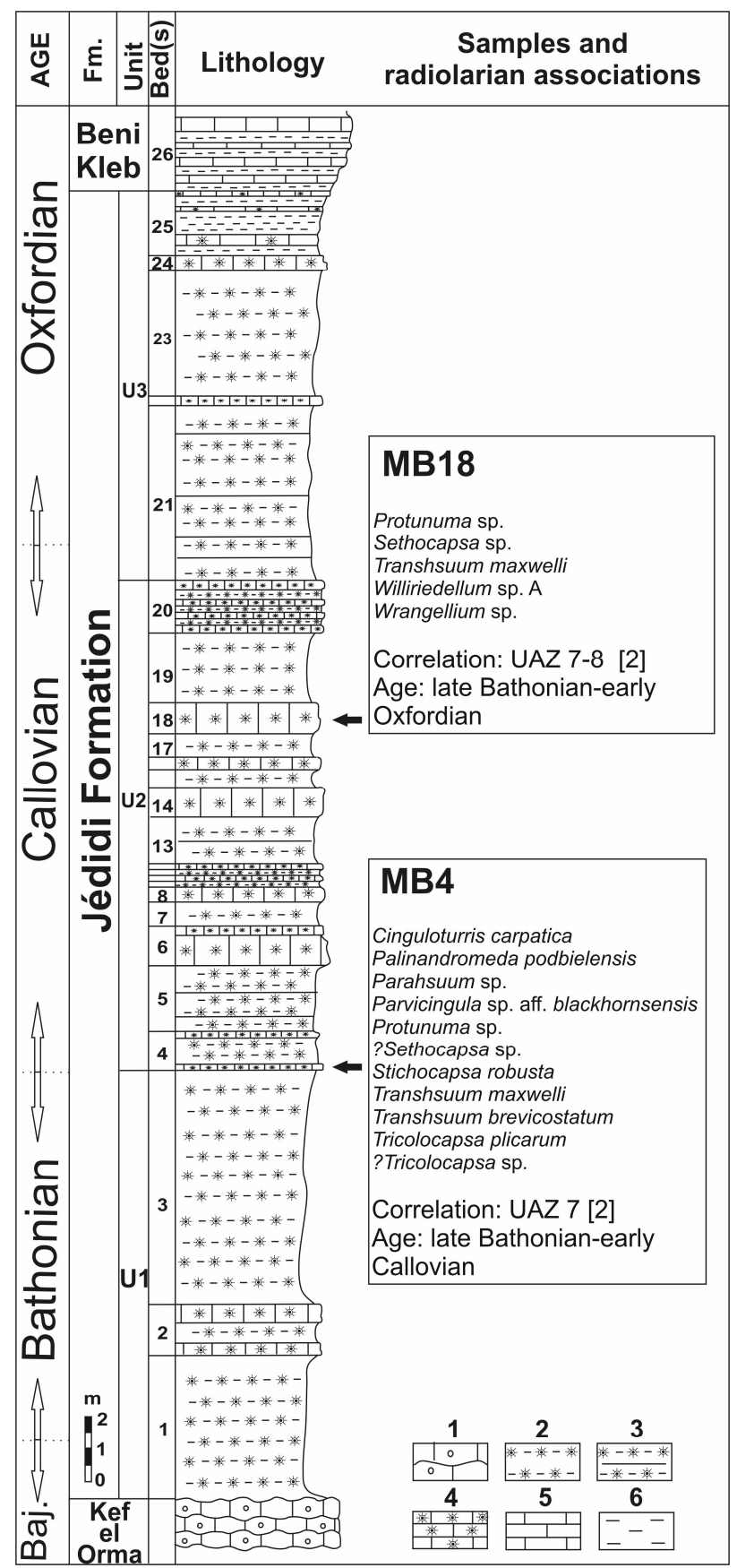

Figure 3 


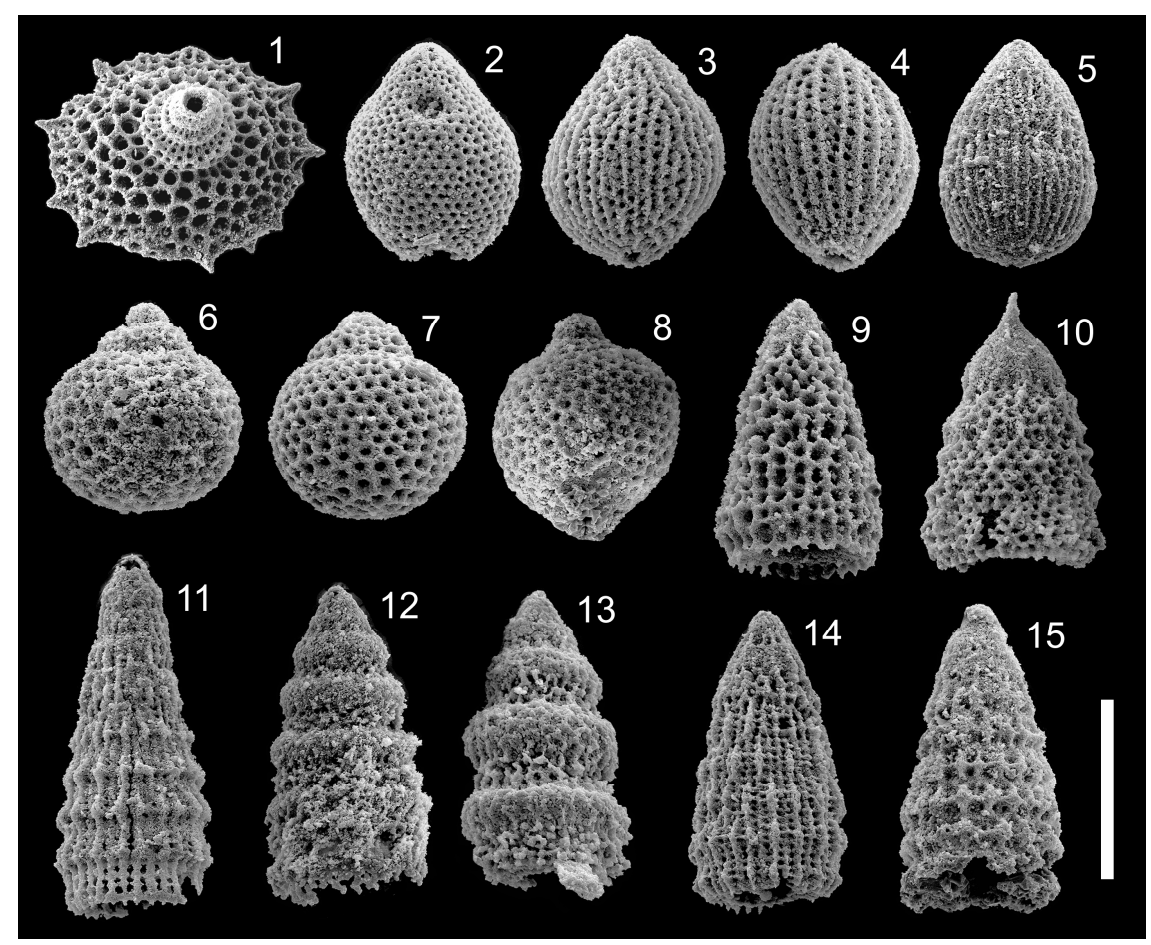

Figure 4 